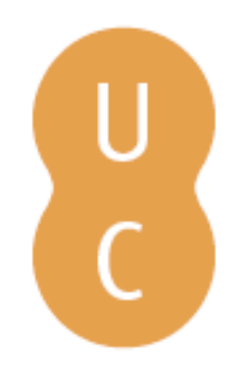

\title{
pompalina
}

\section{The omnipresence of philosophy in Plutarch's Quaestiones Convivales}

\author{
Autor(es): Lopes, Rodolfo
}

Publicado por: Imprensa da Universidade de Coimbra; Centro de Estudos Clássicos e

URL

persistente: URI:http://hdl.handle.net/10316.2/32029

DOI: $\quad$ DOI:http://dx.doi.org/10.14195/978-989-8281-17-3_38

Accessed : $\quad$ 26-Apr-2023 15:42:05

A navegação consulta e descarregamento dos títulos inseridos nas Bibliotecas Digitais UC Digitalis, UC Pombalina e UC Impactum, pressupõem a aceitação plena e sem reservas dos Termos e Condições de Uso destas Bibliotecas Digitais, disponíveis em https://digitalis.uc.pt/pt-pt/termos.

Conforme exposto nos referidos Termos e Condições de Uso, o descarregamento de títulos de acesso restrito requer uma licença válida de autorização devendo o utilizador aceder ao(s) documento(s) a partir de um endereço de IP da instituição detentora da supramencionada licença.

Ao utilizador é apenas permitido o descarregamento para uso pessoal, pelo que o emprego do(s) título(s) descarregado(s) para outro fim, designadamente comercial, carece de autorização do respetivo autor ou editor da obra.

Na medida em que todas as obras da UC Digitalis se encontram protegidas pelo Código do Direito de Autor e Direitos Conexos e demais legislação aplicável, toda a cópia, parcial ou total, deste documento, nos casos em que é legalmente admitida, deverá conter ou fazer-se acompanhar por este aviso.

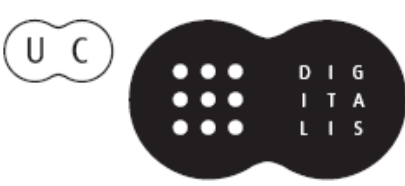




\section{Symposion and Philanthropia in Plutarch}

\section{José Ribeiro Ferreira, Delfim Leão Manuel Troster e Paula Barata Dias (eds.)}

IMPRENSA DA UNIVERSIDADE DE COIMBRA 


\title{
The OMNIPRESENCE OF PHILOSOPHY IN Plutarch's QUAESTIONES CONVIVALES ${ }^{1}$
}

\author{
Rodolfo Lopes \\ University of Coimbra
}

\begin{abstract}
In the following paper I attempt to clarify in which way philosophy is present in the Quaestiones Convivales. I leave aside the role that this work plays as an anthology of Ancient Philosophy and focus on two other aspects that seem to be decisive for an understanding of its architecture: philosophy as a discussion subject, and, more important, as a structural force in this collection of talks. Taking into account the traditional division of Ancient Philosophy in three branches logic, ethics and physics -, I try to show that there are very clear connections between them and those two vectors of analysis: philosophy as a subject of discussing is strictly related with physics, and philosophy as a structural force depends on ethics and logic.
\end{abstract}

\section{Philosophy in the Symposium}

As a code of rituals and symbols of interaction, commensality is a practice that follows Man from time immemorial. Initially found in military, religious and political contexts, and later simply practised as a form of social conduct, human interaction around a table was governed by certain rules and procedures that determined the gathering's development ${ }^{2}$. Even in Homer one can find examples of this kind of reunion, which did not have the specific structure that we know from the archaic and classical periods (namely the division between deipnon and symposion), like the Achaean embassy to Achilles in Iliad Book 9 or Odysseus' arrival at the palace of Alcinous in Odyssey Book 7. In both of them, as in other examples of the same type, the conversation focuses on the intentions of the man who arrives from outside the gathering ${ }^{3}$, and for that reason can be seen to be strictly related to hospitality rituals. After this phase, the sympotic descriptions left by the archaic poets show us an atmosphere of feasting and amusement, in which a primary role was given to the cultivation and dissemination of sung poetry and other forms of music, to ethnographic narratives, and to praise or blame. Briefly, the symposium was a space of amusement, cultural dissemination and remembrance of an heroic past ${ }^{4}$. Still in a context of fun, but already in the classical period, one of the most complete descriptions of a symposium is offered by Aristophanes in his Wasps, in which there are many conversations, but all of them in a jesting context (vv. 1175-1206), culminating in mutual insults and several acts of violence by the drunken symposiasts (vv. 1300-1325).

In all of the above-mentioned examples, the importance of $\lambda$ óyos in the symposium is obvious. However, this $\lambda$ ó

\footnotetext{
${ }^{1}$ I wish to thank Manuel Tröster for his precious help with the English version of this paper and also for his suggestions that helped me to improve it.

${ }^{2}$ Apud O. Murray, 1990, p. 6.

${ }^{3}$ Cf. E. L. Bowie, 1993, p. 357.

${ }^{4}$ Apud W. Rösler, 1990, pp. 231-2 (Cf. E. L. Bowie, 1993, pp. 358-66).
} 
and not yet of "dialogue"; it refers to "speaking" and not "discussing", far less, following Plato, "discussing dialectically"; for the main goal of those gatherings was amusement, and not investigation.

It is not very clear how the transition between the $\lambda$ óyos of "speaking" and the $\lambda$ óyoৎ of "discussing" occurred, or, in other words, how the philosophical symposium came into being, because the works that seem to have been the first of this kind did not survive ${ }^{5}$. According to a fragment from Aristotle (fr. 72 Rose), the first author of a philosophical Symposium was Alexamenos of Styra or Teos, and Diogenes Laertius (3.48) says that the first were Zeno and Protagoras. So it is safer to say that was Plato who initiated the philosophical symposium tradition. It is true that we can not determine whether Plato's Symposium was written before Xenophon's, but, even if it was not, Xenophon says in the beginning of his work that it is a collection of amusing conversations (1.1) and not of philosophical discussions. Besides that, Plato's role in the establishment of the philosophical symposium is not confined to his Symposium: he talks about the rules and requirements of this kind of work in other dialogues too. In the Protagoras, Socrates clearly distinguishes two kinds of symposia: those of common and vulgar

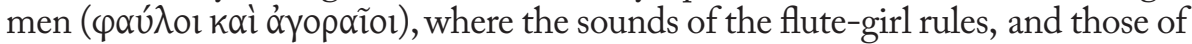
the $k \alpha \lambda$ oi kở $\alpha \theta$ oí, during which everyone talks and listens in an organized way, even if they drink too much wine (347c-e). Likewise, in Plato's Symposium, the decision to dismiss the flute-girl in order that the gathering may be given over to

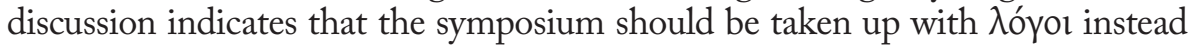
of jokes and amusements, and become a philosophical symposium - a feast of speeches, as Plato says many times (e.g. Grg. 447a; $R$. 352b, 354a-b; Ti. 20c). As for the purpose of those discussions, Socrates makes himself quite clear: it is to make trial of the truth and of the speakers themselves (Prt. 348a).

\section{The Quaestiones Convivales ${ }^{6}$ as a philosophical symposium}

Thus, we must raise the following question concerning the set of symposia that Plutarch presents in the $Q C$ : is it like that of Aristophanes' Wasps or is it closer to Plato's conception? As we shall see, the answer is quite obvious, because, besides the fact that the $Q C$ are almost universally recognised to be a philosophical symposium ${ }^{7}$ - or a set of symposia -, the text itself gives us much evidence that validates this conclusion.

In the very beginning of this work, Plutarch frames the set of symposia that he is about to present to Sosius in a tradition of other authors that did the same before him, like, among others, Plato and Xenophon $(612 \mathrm{E})^{8}$. Thus, he assumes from the start that the $Q C$ belong to a group of works with a philosophical orientation; besides that, the very first question is precisely about

${ }^{5}$ On the origins of the philosophical symposium, see M. Vetta, 2000, pp. 219-22.

${ }^{6}$ From now on, the Quaestiones Convivales will be referred as $Q C$.

${ }^{7}$ See F. KLOtz, 2007, pp. 650, 653; L. Romeri, 2002, p. 109.

${ }^{8}$ Although vast, the list remains incomplete. On this problem, see M. VETTA, 2000, p. 222; S.-T.TeOdorsson, 1989, p. 12. 
the presence of philosophy in the symposia. Thus, by noting so clearly this affiliation with such a tradition, the reader will obviously expect to find in the following pages a set of conversations about serious - even philosophical - matters and not a collection of jokes or other amusing activities, as in the archaic symposia or the one described in the Wasps. Later, in the Prooemium to Book VI, Plutarch confirms this affiliation by insisting on the necessity of writing down all that was said during the banquet, leaving aside everything related to its material side, like the dishes or drinks that were consumed, just like Xenophon and Plato had done (686 D).

On the other hand, these conversations, in order to follow their philosophical legacy, will have to be governed by the rules of proper conversation held by educated people; otherwise it would become the record of a symposium

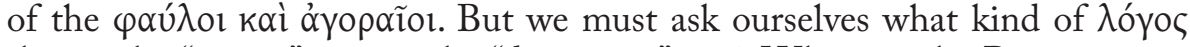
this is: the "saying" one, or the "discussing" one? When, in the Proemium to Book I, Plutarch makes use of the examples of other authors of symposia and says that the task of writing down the conversations held while one drinks is worthy and that, on the other hand, it is wise to forget the improprieties

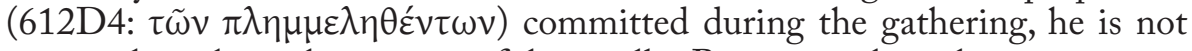
very explicit about the content of those talks. But, to say that what is improper must be forgotten and, at the same time, assuming that something must be written down implies that the things that deserve to be remembered should be something proper.

According to L. Van der Stockt, the $Q C$ follow a model of conversation among polite and moderate men based on the ethical criteria of $\varphi \imath \lambda i ́ \alpha$,

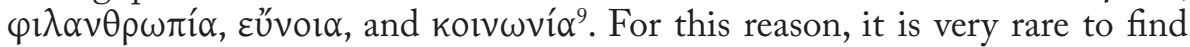
someone exceeding the limits imposed by these values ${ }^{10}$. Hence, we must infer that these parts of the symposia that Plutarch wanted to transmit to posterity through writing have some kind of normative codification as far as concerns the conversation rules. Besides, the main goal of the symposium itself was to cultivate those criteria which govern conversation and, even though there is some room left for certain useful amusements (711A), it is quite clear that there is a supremacy of $\lambda$ ó $\gamma$ oৎ to the disadvantage of the spirit of fun that we find in archaic symposia; for the pleasures generated during the symposium

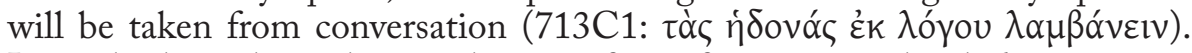
In truth, throughout the $Q G$ there are few references to other ludic activities; for this work is, in a general way, a set of conversations that occurred during symposia, and the meaning of a symposium is to share not only meat and drink but also conversations, which leads to friendship (660B).

Returning to the distinction established by Plato in the Protagoras between

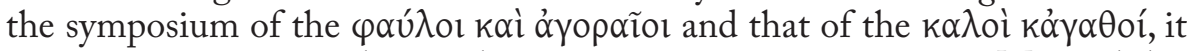
is very curious to note that, in the Septem Sapientium Convivium, Mnesiphilus says that the character of the men Periander had gathered exempted wine

\footnotetext{
${ }^{9}$ L. VAn der Stockt, 2000, p. 94.

${ }^{10}$ See L. Van der Stockt, 2000, pp. 93-4; F. Martín García, 1987, pp. 11-2.
} 
from the symposium on the grounds that conversation, the highest pleasure of a symposium as it combines earnestness and amusement, was already

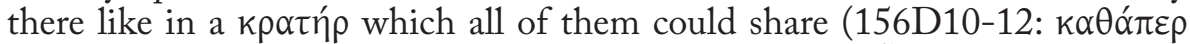

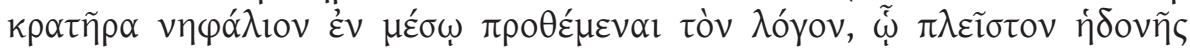

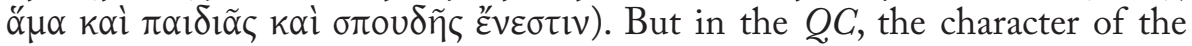
symposiasts is much more diversified, since they gather philosophers, doctors or even farmers at the same table ${ }^{11}$, and, consequently, conversation must

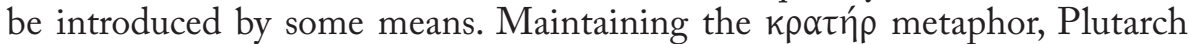
establishes a connection between wine and conversation, conceiving them as ingredients of a sort of blend that will raise or increase the main ethical criteria that govern the symposium: as Dionysus is the Loosener, for he unleashes

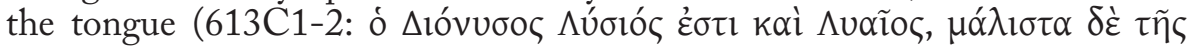

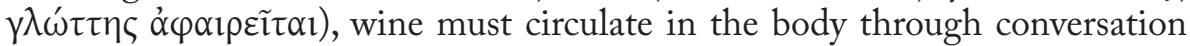
and, blended with it, will take it from the body to the soul (660B11-12: $\dot{\varepsilon} \pi \mathrm{i}$

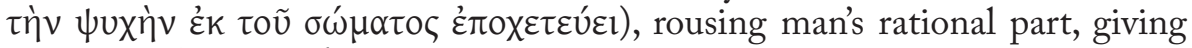
birth to $\varphi \imath \lambda \alpha v \theta \rho \omega \pi i \alpha$, and tying the bonds of friendship. But, on the other hand, if wine circulates throughout the body without any mediation, it will

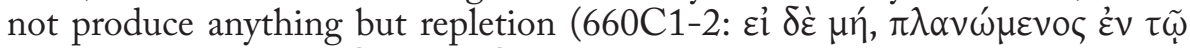

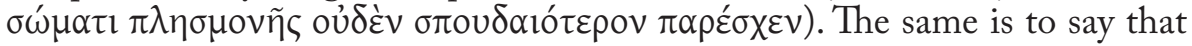
wine must be ruled by $\lambda$ ó $о \varsigma$ and, conversely, wine will generate $\lambda$ ó of this strict correlation and interdependence between wine and conversation, whose equilibrium will determine the symposium's course, both of them must stand at the same level; in order to maintain the convivial spirit in harmony,

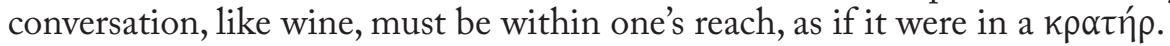

But, more than vain and pointless talk, the concept of conversation in the $Q C$ is very close to philosophical discussion: Plutarch says that, instead of bringing into the symposium activities that would turn themselves into obstacles to entertainment more than into entertainment itself, they should

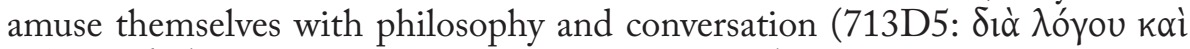

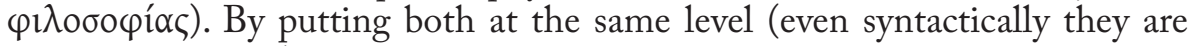
strictly connected), it is obvious that the conversations will necessarily be philosophical. Consequently, one may expect that the symposiasts will define themselves as philosophers and their activity as performative philosophy ${ }^{12}$. In certain sections this is quite evident, particularly when Plutarch refers to some

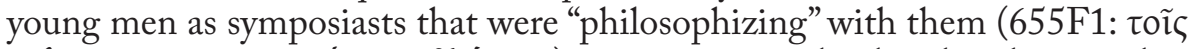

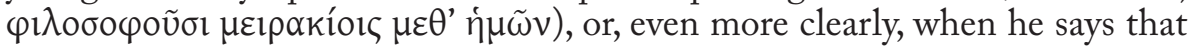
the conversations held in the days before were philosophical questions and

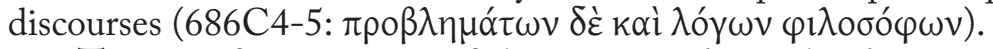

The very first question of the $Q C$ introduces the discussion on the use

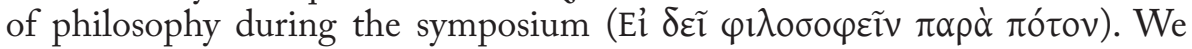
may surely say that its position is not accidental; for it represents a sort of general guideline according to which the conversations will be held and, at a narrative level, they will be displayed in writing. At the same time, it establishes

\footnotetext{
${ }^{11}$ On the diversity of the participants of the QC, see F. KLOTZ, 2007, p. 653.

${ }^{12}$ See F. KLOtz, 2007, pp. 659-ff.
} 
the set of principles which philosophy must obey whenever it is a subject of conversation. Unlike the Persians, who, according to Plutarch, used to keep philosophy far away from the symposium and preferred instead activities more compatible with drinking like dances or mimes (613A), they will accept it in their symposium, but with some restrictions.

As regards the kind of problems to be dealt with, in order to keep intact the main ethical criteria that govern the symposium, the investigations must

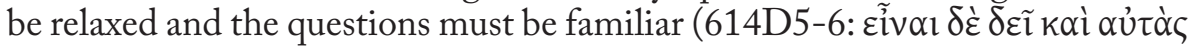

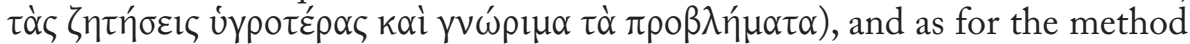
of pursuing those questions, the discussion must be driven by persuasive

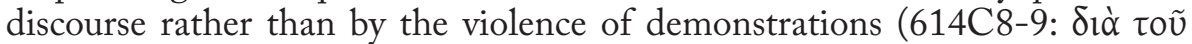

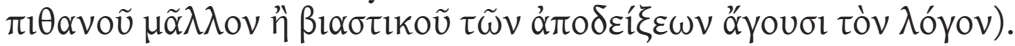

\subsection{Philosophy as a conversation subject (physics)}

Many of the questions in the $Q C$ are designed to solve philosophical issues. Nevertheless, the range of the investigations is generally restricted to natural philosophy; for the diversity of the participants does not allow the discussion of complicated problems, and, for that reason, the emphasis is mainly on physics. Human nature is one of the most recurrent topics, to which Plutarch dedicates several questions, particularly as far as concerns psychology (Problêmata 3.6; 8.10), physiology (Problêmata 2.2; 4.10; 7.1; 8.8; 9.10), the origins or causes of illnesses (Problêmata $6.8 ; 8.9$ ) and the way human beings deal with sensations and affections (Problêmata 1.8; 3.4; 5.1; 6.1-3; 7.3,5; 8.3). On the other hand, since wine is a very important element in the organization of a symposium and since the $Q C$ also deal with questions related to this matter, there are also many questions that focus on the relation between man and wine, most notably its effects (Problêmata 1.6-7; 3.3, 7-9; 3.5). Apart from human nature, there also discussions about other dimensions of the natural world, particularly questions related to animals (Problêmata 2.3, 7-9; 3.10; 4.4; 6.10; 8.8), plants (Problemata 2.6; 3.2; 4.2; 5.9; 6.10), the elements (Problêmata $1.9 ; 6.4-6$ ), and also to astronomy (Problemata $4.7 ; 9.9)$. As for the sources that the participants use to develop their argumentation, although there are dozens of quotations of the principal Aristotelian scientific doctrines, mainly from the Problemata, which at that time were attributed to him, and, generally, from the Peripatetic tradition, one must be cautious in saying that Plutarch follows them in the $Q C$ for two major reasons. First, there are very few situations in which the conclusion of the discussion matches the Aristotelian axiom (659D; 696D; 702B), for the most part these 'quotations' are used either to get a discussion started (650A; 652A; 656B-D; 690C,F; 704F; 720D; 734E; $735 \mathrm{C})$, or, less frequently, they are simply refuted (627A-D; 694D; 724D). Second, in some respects Plutarch clearly follows the Platonic tradition, as in the aforementioned characterization of the human affections and sensations, which is strictly connected with the theories established by Plato in the Timaeus (43c-ff.; 78e-ff). 
In a general way, the preponderance of physical aspects as a conversation subject establishes the $Q C$ as a piece of philosophical investigation by means of encyclopaedic knowledge - a sort of $\pi 0 \lambda u \mu \alpha \dot{\theta} \theta \varepsilon \alpha^{13}$. On the other hand, the observations on natural philosophy are designed to deny some common-sense beliefs, and put forward theories based on scientific knowledge: the cause of problems in navigation is not the fish called remora, but the deterioration of the ship's keel (Problêma 2.7); truffles are not generated by thunderbolts that penetrate the soil, but by the nature of the water that falls with them (Problema 4.2 $)^{14}$; Mithridates was called Dionysus not for drinking too much wine, but because he too had been hit by lightning when he was a child (Problema 1.6).

\subsection{Philosophy as a structural force (ethics and logic)}

As I pointed out before, Plutarch refers to some participants as young symposiasts that are philosophizing with them. Thus, besides discussing philosophy, the organizers of the symposium also seek to initiate the younger participants into these arts of investigating the truth of things. This clearly shows, on the one hand, the pedagogical purpose of the symposium, a matrix also present in the Platonic conception of the symposium ${ }^{15}$, and, on the other hand, a particular concern about the integration of those younger members in the dynamics of the symposium and, hence, in the philosophical method.

However, conceiving that the conversations held in the $Q C$ have a philosophical foundation and accepting as a structural principle that those conversations must be within the range of every participant raises an inevitable

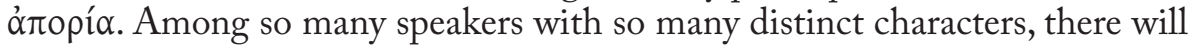
always be some that do not share the same passion for philosophical questions or that simply do not have the capacity to follow the investigations. Blending these two aspects may put at stake some of the primary ethical criteria that regulate the symposium. How does Plutarch solve this problem? The answer is quite simple. He takes advantage of the heterogeneity of the convivial set to create a sort of unity through difference, just like in a symphony, where many instruments coexist in perfect harmony, each one with a different sound and a different nature. In Plutarch's own words, coexistence in the symposium will be like human language, which, although it is composed of dissonant sounds mute consonants and sonant vowels-, is natural and spontaneously harmonious

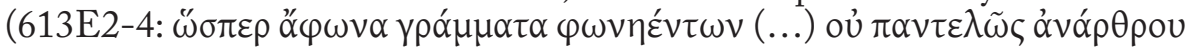

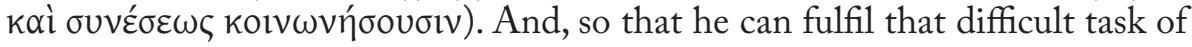
tuning in the differences among the speakers, Plutarch proposes to eliminate conversations of "wranglers" and "thimble-riggers" (614E2-4: ' $\varepsilon 1 \delta \alpha v \tau \varepsilon \dot{\varepsilon} \omega v$ ' $\delta \dot{\varepsilon}$

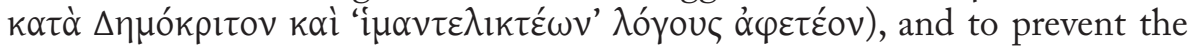
gathering from being carried away to a contest proper to sophists or similar

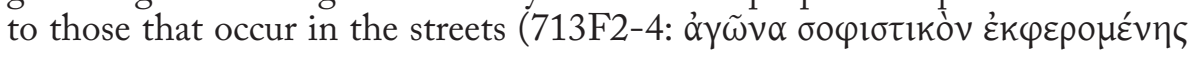

\footnotetext{
13 Apud G. Soury, 1949, p. 321.

${ }^{14} \mathrm{On}$ this particular issue, see in this volume the contribution by A. SETAIoli.

${ }^{15}$ See P1., Lg. 671a.
} 


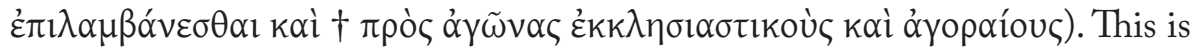
to say that they must investigate accessible and worthy problems and that they must not waste their time with useless riddles, that may embarrass some of those present. Likewise, the rhetorical level must be simple, so that everyone can understand what people are talking about. This is absolutely synchronized with Plutarch's rhetorical conception, which favours a simple form of speech; for the main concern is that the message can be understood ${ }^{16}$. For this reason, they should follow Plato's example, embracing men with exempla and mythical

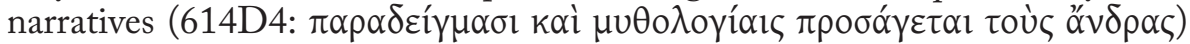
instead of driving them through pure demonstrations.

By proposing a lighter version of philosophy to occupy the symposium, Plutarch seems to pull it down to a lower rank, so that it may be accessible even to those that are not $k \alpha \lambda$ oi $k \alpha \dot{\gamma} \gamma \alpha \theta$ oí. However, conceiving it in purely Stoic terms as

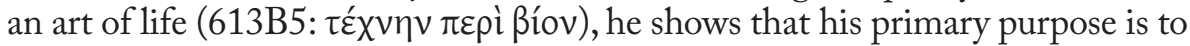
use it in a very pragmatic way, which is a far cry from the metaphysical exercises of his master Plato. Closer to Socrates, whose philosophical system depended upon the set of actions he performed, yet connected to the Stoic ideal, Plutarch detaches philosophy from its metaphysical pedestal and brings it to the real world, so that it may reproduce at a praxiological level what it establishes theoretically, revealing its ability to confirm in actions what it teaches in words (613C7-8:

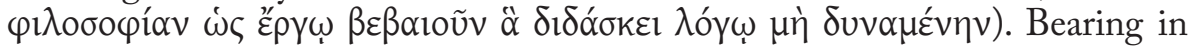
mind that this definition is put forward precisely in the same sentence in which it is said that wine unleashes the tongue, and with both notions being clearly connected, we may easily conclude that, on the one hand, it is wine that allows that $\lambda$ óyos turn into épyov, and, on the other hand, it is that same philosophical $\lambda$ óyos that rules the consumption of wine, thus keeping the ethical criteria of

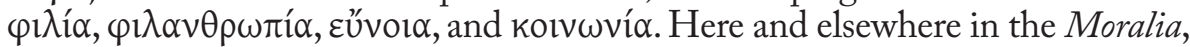
philosophy is a medicine for the soul and its cultivation erases stupidity ( $\left.\alpha^{\prime} v o r \alpha\right)$, derangement $(\pi \alpha \rho \alpha \varphi \rho \circ \sigma u ́ v \eta)$ and lack of education $\left(\alpha \pi_{\alpha} \alpha \delta \varepsilon v \sigma i \alpha\right)^{17}$, which contaminate the ideal state of the symposium.

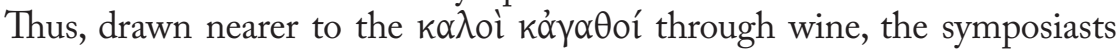

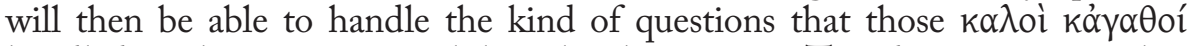
handled in their symposia: philosophical questions. This does not mean that the $Q C$ are a work of pure philosophy (like a treatise), but, as we shall see, the goal to which they aspire is purely philosophical. The very denomination of each book section - $\pi \rho o ́ \beta \lambda \eta \mu \alpha$ - shows that the main challenge that the symposiasts are willing to take up is to surpass each one of those obstacles by means of logical reasoning, each one of them demanding an investigation method that will solve the puzzle and, consequently, find its cause. As Plutarch says, it is at the point where the explanation of a cause fails that one begins to be puzzled,

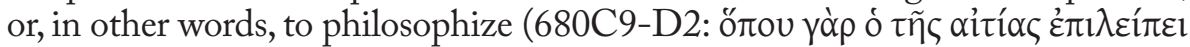

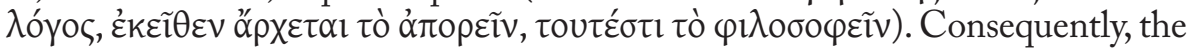
purpose of the conversations held in the $Q G$, whether or not their subject matter

\footnotetext{
${ }^{16}$ Apud G. Matino, 1991, pp. 295-6, 313.

17 Apud F. Becchi, 1999, p. 27.
} 
is philosophy (physics, as we have seen), is to determine the causes ( $\alpha i t i ́ \alpha)$ of a certain problem by means of an investigation $\left(\zeta \eta^{\prime} \tau \eta \sigma \varsigma\right)^{18}-$ in truth, there are, throughout the $Q C$, dozens of occurrences of the words $\zeta \eta \dot{\tau} \eta \sigma r \varsigma^{19}$ and $\alpha i \tau^{\prime} \alpha^{20}$; many times, the latter is part of a $\pi \rho o ́ \beta \lambda \eta \eta \alpha$ title (Problêmata 5.3, 6, 9; 6.1, 4, 5, $6,8,10 ; 9.2,7,9)$; besides that, most of these titles begin with similar expressions

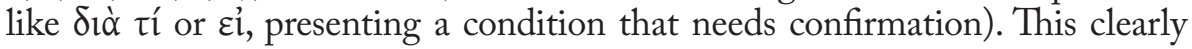
shows the omnipresence of this spirit of philosophical search.

Of course, this does not mean that a unanimous conclusion must result from every discussion; on the contrary, the purpose is to have conversations, about philosophical questions or otherwise, that allow the symposiasts to exercise the faculty of thinking in a group setting, of discussing dialectically. When, at a certain point, the participants take into consideration the veracity of certain questions, more precisely, whether they ought to discuss what may not be true (628B), Marcus, the grammarian, relates the story of Democritus, who, even when he realized that, after all, the cucumber that he was eating was sweet because his maid had left it inside a honey pot, even so he decided to investigate the cause of that sweetness as if it was related to the place where it had grown, as he had thought in the first place (628C-D). Like Democritus, they should assume that the conclusion itself must not determine their investigation, for the discussion,

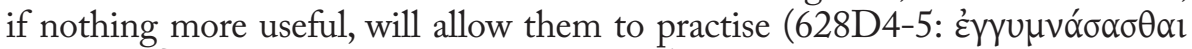

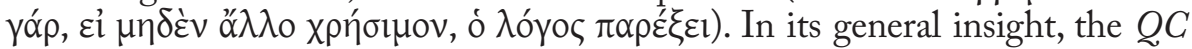
display a scientific spirit very similar to the one that pervaded Plato's Academy ${ }^{21}$; on this particular issue, that relation is quite obvious. According to a fragment of Epicrates (fr. 11 Edmonds), Plato gathered his new students in the gymnasia of the Academy to observe and define every element of the natural world; but, when they tried to define a pumpkin, many problems arose, since this object belonged to more than one category. In spite of that, Plato told them to try again, because the purpose was to practice the method of defining an object, more than to establish a definition itself.

\section{Conclusions}

Concluding this brief investigation, we now may ask: in what way is philosophy omnipresent in the QC? I think the answer depends on three different factors.

First, the structure of this work is framed according to the three branches of

18 Apud L. VAn der Stockt, 2000, p. 96.

${ }^{19}$ 612E13; 614D6, E1; 619B2; 628B10, D1; 636A7; 646A8; 651A2; 664D6; 667E1; 673C9; 675E10; 683C2; 700C3, E4, F5; 701A4; 713F2; 714D5; 725A3; 726C9; 747B6.

20 617E9; 618D4; 619B9; 624A8; 625A7, F5; 626F3; 627A4; 628B9, C6, D1; 635B4, D4, F3; 639D8; 640C3; 641C7, 10, D10; 642A5; 649D4, E5; 650A5, 10; 656C5, D4; 657F4; 658C12; 664C7, D7, 12; 665D3, E1, 8; 666A5, D9, E4; 670A6, B5; 673C9; 676A11; 677C3; 678F1; 679C7; 680C5, 9,F2-3; 682F3; 689C8, E10; 690F5; 691C8; 693B9; 694B11; 696E8, F4; 699E4; 700C9, D4, 11; 701A3, E6; 702B10; 704E12; 722D2; 725A3, B5; 728E7; 729A10, E5; 730B7; 731A2, D2, 6; 732A2; 733D3; 734E4; 737E4; 740B2, D8; 741B10; 744C4; 745D3.

${ }^{21}$ Apud L. Van der Stockт, 2000, pp. 97-8. 
ancient philosophy ${ }^{22}$. Physics constitutes a major percentage of the conversation subjects treated in the Problemata. Analyzing it from a global perspective, the aprioristic system that Plutarch proposes tries to display the main aspects of the human being and its relation with the sensible world while, at the same time, denying common-sense opinions about these questions. After all, this is the major concern of a work about natural philosophy. Ethics allows the participants to talk about many questions (philosophical or otherwise) according to a model of a regulated relationship, which, on the one hand, enables every symposiast to participate in the discussion and, on the other hand, generates and augments the main ethical criteria of the symposium. As for logic, it provides the instruments to discuss the various matters proposed throughout the Problemata, allowing the investigations to be ruled by a dialectical metastructure that puts the argumentative level of the conversation very near to that one of the Academy. Consequently, those who are learning may interact with those who know philosophy and thereby learn the means of achieving the truth more than the truth itself - for instance, Plutarch's brother Lamprias deduced Hieronymus' theory of vision, even though he did not know his book (626A).

Second, this omnipresence gains even more consistency through the unitary correlation that the three branches achieve together; for they are strictly connected and depend upon one another. It would not be possible to discuss questions of natural philosophy without the means provided by argumentative logic; nor would it be possible to talk about any philosophical question whatsoever if the ethical code had not been established. Instead of separating three branches of philosophy, the structure of the $Q C$ is thus framed according to their interconnection and interdependence.

Third, if we ought to consider the symposia that Plutarch describes as a sample of human interaction, as I think we should, the definition of philosophy

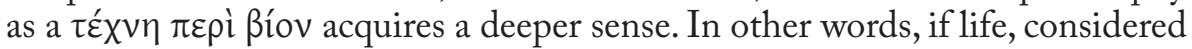
as human performance, is, or must be, regulated, guided and understood through philosophy, the symposium, being a sample of life, will consequently display the same relation with philosophy.

\section{Works Cited}

Becchi, F., "Plutarco fra Platonismo e Aristotelismo: la Filosofia como $\pi \alpha i \delta \varepsilon i ́ \alpha$ dell'Anima”, in A. Pérez Jiménez et AL. (eds.), Plutarco, Platón y Aristóteles. Actas del V Congreso Internacional de la I.P.S. (MadridCuenca, 4-7 de Mayo, 1999), Madrid, 1999, pp. 25-43.

Bowie, E. L., “Greek Table-Talk before Plato”, Rhetorica, XI.4 (Autumn 1993) 355-71.

Klotz, F., "Portraits of the Philosopher: Plutarch's Self-Presentation in the

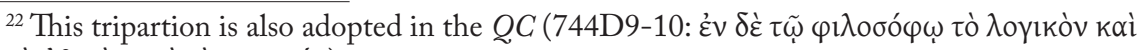

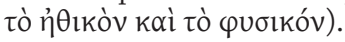


Quaestiones Convivales", CQ, 57.2 (2007) 650-67.

Martín García, F., Plutarco. Obras Morales y de Costumbres (Moralia) IV (Charlas de Sobremesa), Madrid, 1987.

Matino, G., "Strutture Retoriche e Colloquiali nelle Quaestiones Convivales", in G. D'Ippolito \& I. Gallo (eds.), Strutture Formali dei Moralia di Plutarco. Atti del III Convegno Plutarcheo (Palermo, 3-5 Maggio, 1989), Napoli, 1991, pp. 295-313.

Murray, O., "Sympotic History", in O. Murray (ed.), Sympotica: a Symposium on Symposion, Oxford, 1990, pp. 3-13.

Romeri, L., Philosophes entre Mots et Mets. Plutarque, Lucien et Athénée autour de la Table de Platon, Grenoble, 2002.

Rösler, W., "Mnemosyne in the Symposion", in O. Murray (ed.), Sympotica: a Symposium on Symposion, Oxford, 1990, pp. 230-7.

Soury, G., "Les Questions de Table et la Philosophie Religieuse de Plutarque", REG, 62 (1949) 320-27.

Teodorsson, S.-T., A Commentary on Plutarch's Table-Talks, I, Göteborg, 1989.

Van der Stockt, L., "Aspects of the Ethics and Poetics of the Dialogue in the Corpus Plutarcheum", in I. Gallo \& C. Moreschini (eds.), I Generi Letterari in Plutarco. Atti del VIII Convegno Plutarcheo (Pisa, 2-4 Giugno, 1999), Napoli, 2000, pp. 93-116.

Vetta, M., "Plutarco e il 'Genere Simposio", in I. Gallo \& C. Moreschini (eds.), I Generi Letterari in Plutarco. Atti del VIII Convegno Plutarcheo (Pisa, 2-4 Giugno, 1999), Napoli, 2000, pp. 217-29. 